\title{
Türkçe Ders Kitaplarındaki Bilişsel ve Üstbilişsel İşlevlere Dair Bir Durum Tespiti
}

\author{
A Case Study on Cognitive and Metacognitive Functions in \\ Turkish Textbooks
}

\begin{abstract}
Özay KARADAĞ ${ }^{* *}$, Hacer TEKERCIOĞLU***
Öz: Bu çalışmanın amacı, Türkçe ders kitaplarının hangi bilişsel ve üst bilişsel işlevleri kapsadığını belirlemek ve öğretmenlerin bu işlevlere yönelik algı durumlarını ortaya koymaktır. Araştırma, nitel araştırma desenlerinden iç içe geçmiş çoklu durum deseni ile hazırlanmıştır. Çalışmada kullanılan veri toplama araçları, standartlaştırılmış açık uçlu görüşme soruları, uzman görüşü alınarak hazırlanmış bilişsel ve üstbilişsel işlevler ölçütü ve doküman analizidir. Araştırmadan elde edilen veriler, içerik analizi ile kategorize edilmiş ve açıklanmıştır. Çalışmanın sonucunda, Türkçe ders kitaplarındaki bilişsel ve üstbilişsel işlevlerin homojen bir dağılım göstermediği ortaya çıkmıştır. Ders kitaplarında yer alan etkinlikler, kazanımların etkinliğe dönüştürüldüğü örnekler olmuştur. Üstbilişsel işlevler, ders kitaplarında sonuç odaklı ölçme değerlendirme araçları olmuş, metin ya da metne bağlı hazırlanan etkinlikler bu işlevleri geliştirecek şekilde ders kitaplarında yer almamıştır. Öğretmenlerin, bilişsel ve üstbilişsel işlevler konusunda sezgisel bir öğretim metodu benimsedikleri, bunun yanında metinleri ve metne bağlı hazırlanan etkinlikleri bu işlevler bakımından değerlendirmedikleri ortaya çıkmıştır.
\end{abstract}

Anahtar Kelimeler: Biliş, üstbiliş, metin, türkçe ders kitapları, öğretmen farkındalığı

\begin{abstract}
The aim of this study is to determine the cognitive and metacognitive functions of the Turkish textbooks and to reveal the teachers' perception of these functions. The research has been prepared with a multi-case pattern intertwined from qualitative research designs. The data collection tools used in the study were standardized open-ended interview questions, cognitive and metacognitive functions criterion and document analysis prepared with expert opinion. The data obtained from the research were categorized and explained by content analysis. As a result of the study, it was found that cognitive and metacognitive functions in Turkish textbooks did not show a homogeneous distribution. The activities in the textbooks were examples in which the gains were transformed into activities. Metacognitive functions have been result-oriented assessment tools in textbooks, and text or text-based activities have not been included in textbooks in a way to improve these functions. It was revealed that the teachers adopted an intuitive teaching method about cognitive and metacognitive functions, and they did not evaluate the texts and the activities related to the text in terms of these functions.
\end{abstract}

Keywords: Cognitive, metacognitive, text, turkish textbooks, teacher awareness

\section{Giriş}

Bu çalışmanın amacı, Türkçe ders kitaplarının hangi bilişsel ve üst bilişsel işlevleri kapsadığını belirlemek ve öğretmenlerin bu süreçlere yönelik görüşlerini ortaya koymaktır. Bu amaç için çalışmada, "Türkçe ders kitapları hangi bilişsel ve üst bilişsel işlevleri geliştirecek metinleri ve etkinlikleri kapsamaktadır, öğretmenlerin bu konudaki görüşleri nelerdir?” sorusu problem olarak ele alınmıştır. Yapılan bu çalışmanın öğretim programı hazırlanması ve kitap yazımı sırasında sürecindeki uzmanlara bir perspektif kazandıracağı düşünülmektedir. Zira metinlerin derin yapısının çözümlenmesi için öğretmen yeterliliğinin çok önemli bir unsur olduğu eğitim

\footnotetext{
* Bu makale birinci yazarın danışmanlığında yürütülen "Türkçe Ders Kitaplarındaki Bilişsel ve Üstbilişsel İşlevler Üzerine Bir Değerlendirme" adlı yüksek lisans tezinden üretilmiştir.

** Doç. Dr. Hacettepe Üniversitesi, Eğitim Fakültesi, Ankara-Türkiye, ORCID: 0000-0003-4596-1203, e-posta: ozaykaradag@hacettepe.edu.tr

*** Doktora Öğrencisi, Gazi Üniversitesi, Ankara-Türkiye, ORCID: 0000-0001-9901-9657, e-posta: hcr984@gmail.com
} 
geleneğimiz içerisinde yaşanan sorunlardan edinilen deneyimlerle kendini apaçık bir biçimde ortaya koymuştur. $\mathrm{Bu}$ bakımdan araştırmanın önemi, sürecin en başından en sonuna kadar devam eden döngüde, güçlü bir zihinsel zemin ve bakış açısının yaratılmasında hem araştırmacılara hem de uygulayıcılara yeni perspektif sunmak olacaktır.

İnsan, zaman ve mekan içerisinde bilinç ve kimliğini tanımlar.Biliş, bireyin şuur ekseninde mekân ve zaman arasındaki yankılanmasının bir ürünü olarak ortaya çıkmaktadır. Eğitim süreci içerisinde bilişin ön plana çıkarılması dün ile bugünün intibaı arasındaki farkın bireye sezdirilmesi amacı üzerine teşekkül etmiştir. Öğrenme (idrak etme) ve hatırlama arasındaki bilişsel yük, kavramsal ve niteliksel olarak da birbirinden oldukça farklıdır. Üstbilişsel süreçler ise bireyin kendi öğrenme yöntemini tanımlayıp bu eylemi gerçekleştirirken kullanacağı süreçleri kapsamaktadır. Bu süreç bireyin düşünme eylemine yönelik sorduğu sorulardan meydana gelen yine bireysel bir üretimin olduğu daha kapsamlı ve yine kognitif bir süreçtir. Bu süreçleri Türkçe dersi özelinde, ders kitaplarında dil becerileri perspektifinde görmek mümkündür.

Türkçe eğitiminin en kolay ulaşılabilir ve işlevsel materyali ders kitapları olarak görülmektedir.Literatür incelendiğinde, çok sayıda çalışmanın materyali olarak kullanılan Türkçe ders kitaplarının içindeki metinler ve metin altı sorularının, bilişsel ve üst bilişsel işlevler bakımından değerlendirilmedikleri görülmüştür.Bu bakış açısı literatür incelendiğinde de kendini açık bir biçimde ortaya koymaktadır. Zira ders kitapları öğretim programları, metin türleri, dil becerileri, sosyolojik unsurlar, dil bilgisi, ölçme ve değerlendirme süreçleri gibi ölçütler bağlamında birçok çalışmanın ana unsuru olmuştur (Çalışkan, 2016; Ekmen, 2009; Köçer, 2010; Kan, 2010; Şahin, 2015; Solak ve Yayl1, 2009; Yurt ve Arslan, 2014).

Metinlerin çok yönlü birer materyal olmaları, öğretim sürecini birçok bakımdan ihya edebilecek bir etken olarak karşımıza çıkmaktadır. Zira, yaşama dönük ve kendi öğrenmesini tanıyan ve problemlere çözüm üretebilen bir toplum arayışı eğitimin ulaşmak istediği nihai hedeftir. $\mathrm{Bu}$ bakımdan üstbilişin literatüre bakıldığında mazisinin bu amaç üzerinde teşekkül ettiği görülmektedir. Üstbiliş ile ilgili yapılan ilk çalışmalar temelde bellek ve problem çözme becerisi üzerinde yükselmiştir (Brown, 1977; Flavell, 1976, 1979; Vygotsky, 1978). Buradan hareketle yapılan çalışmaların temel noktası bu iki uç arasında gidip gelmiştir yorumu yapılabilir. Amerika'da 1950'lerin başından itibaren işlenegelen bu mesele, Türkiye'de önce bilişsel taksonomi etrafında ortaya çıkmış, ardından 2000'lerin başından itibaren de üstbiliş ile ilgili çalışmalara doğru bir yönelim olmuştur. Üstbiliş, ülkemizde 1997'den günümüze biliş bilgisi (Erden ve Akman, 1997), yürütücü biliş (Senemoğlu, 2018), biliş ötesi- üstbiliş (Çakıroğlu, 2007; Çiçekçioğlu, 2003, Demirel, 2001; Demirsöz, 2010; Duru, 2007; Erdoğan, 2007; Olgun, 2006; Okur, 2008; Özsoy, 2006), zihin üstü (Topçu, 2005), bilişüstü (Özcan, 2007; Yabaş, 2008) ve biliş farkındalığı-bilişsel farkındalık (Demirel ve Turan, 2010; Özkan ve Bümen, 2014) gibi farklı terimler kullanılarak çeşitli yönlerden mercek altına alınmıştır (Baş ve Özturan- Sağırlı, 2017, s. 3).

$\mathrm{Bu}$ bilimsel gelişmeler ve ilerlemeler ile bilişsel beceriler, üstbilişsel stratejiler, öğretmen ve öğrencinin bilgiye, kendine yönelik farkındalıkları, dört dil becerisinin özdüzenleme stratejisi yolu ile ne denli geliştiği, özdeğerlendirme yolu ile süreç içerisinde bireyin kendini objektif ölçütler doğrultusunda nasıl kritik edip tanımladığı gibi meseleler üzerinden eğitim ve öğretime dair yeni bakış açıları sunulmuştur. Bu bağlamda bilişin gelişim ve faaliyetlerini detaylandırmak gerekmektedir.

\section{Bilişsel gelişim ve faaliyetler}

Tüm zihinsel faaliyetlerimiz "bir şey" ile ilgilidir (Smith ve Kosslyn, 2014:11 çev. Nakşidil Yazıhan). "Şey" kavramı epistemolojik ve ontolojik bir sorunsaldır. Zihin, bu problem üzerine eylemler ortaya koyarken kendisi üzerinde temsiller aracıllğıyla ihtimaller inşa eder, onları yıkar ve dahi yeniden kurar. Zihin, bu inşa ve yıkımı "anlam" arayışı üzerinde gerçekleştirir. Beyin, anlam ve bilişe dair nosyonların toplandığı bir işlemleme sistemidir. Bu işlemleme yani beyin aktivitesi esas olarak nöronların aktivitesi ile ortaya çıkar (Smith ve Kosslyn, 2014, s. 17). Nöronlar temelde duyusal nöron-duyusal girdiler aktivite olmasını sağlar- ve motor nöron- 
kasların uyarılması ile aktivite eder- olarak ikiye ayrılır. Nöronların diğer birimleri ise dendritler, akson ve hücre gövdesidir. Nöronların arasındaki etkileșim sinapslar (sinaptik aralık) aracılığı ile gerçekleşir. Bu etkileşim yeni bir bilgi girdisini, eski bilgiler arasındaki ilişkiyi, var olan bir bilgiyi geri çağırmayı ve bir problem çözümünde kullanmayı kapsamaktadır. Buna bağlı olarak da alg1, dikkat, bellek, kodlama, geri çağırma, karar verme, problem çözme ve akıl yürütme, dilsel faaliyetler gibi süreçler bilişsel süreçleri meydana getirir. Eğitim açısından bilişsel anlamda gerçekleşen hiyerarşi taksonomik olarak da ifade edilmektedir.

\section{Bilişin taksonomisi}

Yaşanılan sosyolojik olaylar, insan bilinci ve düşüncesini derinden etkileyen yapıdadır. Hatta o kadar derinden etkiler ki kavramlara yönelik değişim ve dönüşümü de beraberinde getirir. İki bloğa ayrılmış bir dünyanın varlığı söz konusu olduğunda ve bu dünyanın artık elinde bulunan bilgi birikimini raflara yerleştirmesi gerektiği fikri haiz olduğu anda, bu gergin birer tel gibi iki farklı konsolidasyonun ortaya çıkmasıyla oluşan yeni dünya, bir kütüphane düzeninin yanı sıra fonksiyonel birtakım olgularla hareket etmek durumunda kalmıştır, bunun için de bloklara ayrılmış olan yeni dünya, kurduğu düzenin dizaynında fonksiyonel bir kaygıyla hareket etmeye başlamıştır. Bu bağlamda bilginin varlığı, sıralanması, gruplandırılması, tatbiki, çözümlenmesi, bireşimi bilgi toplumunu tanımlayan anahtar kavramlar olmuştur. Soğuk savaşın ardından modernist düşüncenin etkisiyle bilgiyi kategorize etme eğilimi iki blok haline ayrılmış dünyanın temel özelliklerinden biri olarak ortaya çıkmıştır. Bu bağlamda "Sputnik Era" olarak bilinen bu bilgi toplumu çağı, eğitimi de derinden etkileyerek şekillendirmiştir. Eğitim, bilginin işlenmesi ve öğretilmesi sırasında kendine yeni bir yöntem çizmiş, buna mukabil hiyerarşik bir yap1 kurmuştur.

Literatürde Bloom Taksonomisi olarak adlandırılan bu aşamalı sınıflama, bir bakıma kontrol sistemi görevini de yerine getirmiştir. Zira, ortaya çıkan davranış(bilgi) kontrol edilirken birtakım kriterler göz önünde bulundurulmuş ve ilişsisel bir hiyerarşi söz konusu olmuştur. En alt basamakta yer alan bilişsel düzey, en üst basamağı oluşturan yapı taşları görevini görmüştür çünkü alt basamaklarda yer alan bilişsel düzeyi yerine getirmeden bir üst basamağa geçmek mümkün görülmeyen bir olgu olmuştur. Tüm bunlara rağmen Bloom (1956) ve sonrasında ortaya konulan tüm sinıflandırmaların Krathwohl (2002) bilişin ürettiği bilince dair emareler sunduğu yadsınmamalıdır. Üstbiliş de tıpkı biliş gibi kavramsal anlamda son şeklini alacak çeşitli bulguları halen beklemektedir. $\mathrm{Bu}$ bağlamda literatürde üstbiliş ile ilgili değerlendirmeleri ortaya koymak yerinde olacaktır.

\section{Yekpare bir biliş yahut kurucu özne: üstbiliş}

Bireyin kendi kıyısına geçip kendisi hakkında bilgi sahibi olması ya da kendisinin farkında olması ontolojik, bilişsel ve epistemolojik anlamda üst düzey bir yeti ve durumdur. Bu bağlamda insan bilincinin tüm paradigmaları (dizi), düşünmeye dair süreçler ve özellikler, bireyin benliğini şekillendiren ve onun "alg1 süreçlerine" dair izleri ortaya koyan birer ayna parçalarıdır. Bireyin kendine ait bilgisi, -eğitimin amaçları göz önüne alındığında akla ilk gelen amaçlardan biri olmaktadır- belki de eğitim yoluyla ulaşmak istenilen nihai amaçlardan bir tanesi olabilir. Zira ben ve öteki arasındaki ayrımı sağlayabilmiş olan bir bilinç (zihin), kendisinde olan gedikleri ya da fazlalıkları bilerek yola devam ettiği için öğrenme denilen olguyu ne şekilde sağlayacağını ve bundan neler elde edebileceğine ilişkin beklentileri oluştururken oldukça bilinçli bir süreci işletmekten geri durmaz.

Bir sürerlik ve ilişkisellik üzere kurulu olan bilim, üstbiliş çalışmaları konusunda da aynı özelliği sergilemiştir. Bu sebeple üstbiliş adına yapılan çalışmaların kökeni Piaget'ye (1939) dayanan bir maziye sahiptir. Zira onun ortaya koyduğu görüşe göre, bir çocuğun bilişsel gelişiminin başladığ 1 dönem egosantrik dönemi içine alan zaman aralığıdır. Piaget (1939), çocuğun kendi bilinci konusunda az da olsa farkındalığa sahip olduğunu ancak kendisinin dışında kalan bireylere yönelik bir farkındalığının henüz tam anlamıyla oluşmadığını ortaya koyar. Bunun sebebini de yaşantının azlığı, duygu ve düşüncenin henüz tam anlamıyla deneyimlenmemesi olarak gösterir. 1970'lerin başından itibaren ise, önce metamemory ardından 
da metacognition kavramı ortaya çıkmıştır (Brown, 1977; Flavell, 1979; Osman ve Hannafin, 1992; Schraw ve Dennison, 1994; Wellman, 1985; Zimmerman, 2000). Bu çalışma kapsamında iki üstbiliş teorisi üzerinden durulacaktır: Flavell (1979) ve Brown'ın (1987) üstbiliş teorisi.

\section{Flavell ve üstbiliş teorisi}

Flavell (1979) okul öncesi ve ilkokul düzeyindeki öğrencilerin belleklerinin daha güçlü olduğuna dair bir yargıyı deneyimlemek adına bahsi geçen gruplarla bir çalışma yapmaya başlamıştır. Çalışmanın sonunda çocukların yaşları küçüldükçe yeni kavram ve durumları tanımlamakta zorlandıkları, kendi öğrenmelerine dair -görece daha büyük yaşlardaki çocuklardan- daha az iç gözlem yaptıkları ortaya konulmuştur (Flavell, 1979: 906). Onu, bu konuda bu denli kapsamlı araştırma yapmaya iten argüman ise şu olmuştur: Üstbiliş, bilgi paylaşımı, ikna becerisi, konuşma-anlama, okuma- anlama, yazma, dil edinimi, dikkat, bellek, problem çözme, sosyal biliş, özdenetim, özyönetim gibi konularda ayrıca sosyal öğrenme teorisi de benzer fikirlerden hareket ederek üstbilişin iletişimde önemli bir işleve sahip olduğunu açıkça söyler. Bilişsel değişim, kişisel gelişim ve kişiliğin eğitiminde önemli rol oynar (Flavell, 1979:906). Gelişim alanları göz önünde bulundurulduğunda, bireyin nihai hedefinin kendi kimliğini inşa edip onun kontrol mekanizmalarını yönetebilmek olduğu ortaya çıkmıştır denilebilir. Buna istinaden o dönemde metacognition kavram alanının yeni bir çalışma alanı olmasının gerekliliği açık bir biçimde tezahür etmiştir.

\section{Brown ve üstbiliş teorisi}

Flavell'in ardından üstbiliş literatürüne önemli katkılarda bulunanlardan biri de Ann Brown'dır. Brown (1987), teorisinde planlama, izleme, yeniden düzenleme ve gözden geçirme gibi yönetici stratejilere vurgu yapmıştır (Akın ve Abacı, 2011, s. 74). Flavell'in (1979) aksine Brown (1987) üstbilişsel süreçlerin duygu içermeyen ve amaçlı bir unsur olduğunu iddia etmiştir. Flavell (1979), bir durumla ilgili yaşanan başarısızlık sonucunda ya da bilişin içerisindeki bilgi eksikliği durumunda ortaya çıkan duygu durumundan söz etmiş ve bunun bilinçli bir süreç olup olmadığına dair net bir açıklama sunmamıştır. Brown (1977), metabiliş kavramının aslında problem çözme becerisinin yan çıktısı olduğunu öne sürmüş, bahsi geçen diğer kavramların ana merkezinin problem çözme becerisi olduğunu savunmuştur. Brown'a (1987) göre üstbiliş, bilgiyi kavramayı ifade eder (s. 65). Kastettiği kavrama ise çok yönlü bir özellik sergiler, hem tanımlanmalı hem de fonksiyonel bir biçimde kullanılmalı ancak bu takdirde gerçek bir kavrama söz konusu olabilir.

\section{Yöntem}

$\mathrm{Bu}$ araştırmada nitel araştırma desenlerinden durum çalışması kullanılmıştır. Dört tür durum deseninden iç içe geçmiş çoklu durum deseni -uzman görüşü alınarak belirlenen bilişsel ve üstbilişsel işlevler ölçütlerinin alt boyutlarının olması sebebiyle- araştırmanın yöntemini oluşturmuştur. İç içe geçmiş çoklu durum deseninde, ele alınan veya araştırmaya dahil edilen her bir durum, kendi içinde çeşitli alt birimlere ayrılarak çalışılabilir (Yıldırım ve Şimşek, 2018, s. 302). Bu bakımdan çalışma boyunca bilişsel ve üstbilişsel işlevler kendi içinde de alt kategorilere ayrılmış, öğretmen görüşleri için hazırlanan sorular da bu çalışma deseni sebebiyle alt ve üst kategori ilkesince şekillendirilmiştir.

\section{Araştırmanın inceleme nesnesi}

Araştırmada amaçlı örnekleme yöntemlerinden ölçüt örnekleme kullanılmıştır. Ölçüt örnekleme yöntemindeki temel anlayış bir dizi ölçütü karşılayan bütün durumların çalışılması (Yıldırım ve Şimşek, 2018: 122) olarak tanımlanmış, bu çalışma dahilinde söz edilen ölçütler şu işlem basamakları sonucunda belirlenmiştir:

1. Bilişsel ve üstbilişsel işlevlerin tespiti için Millî Eğitim Bakanlığı (MEB) tarafından 2018 öğretim programı kapsamında (2018-2019 öğretim yılı için) hazırlanan MEB Yayınlarına ait ders kitapları seçilmiştir. Bu ders kitabı seçimi için uzman görüşüne başvurulmamıştır, zira kitapların kullanıma hazırlanmasından evvelki denetlenme 
süreçleri ve bunların yaygın kullanımı ders kitaplarının araştırmanın inceleme nesnesi olmasına zemin hazırlayan kriterler olmuştur. Araştırmanın inceleme nesnesine ait bilgiler Tablo 1'de verilmiştir:

Tablo 1.

Ders Kitapları Listesi

\begin{tabular}{lcc}
\hline \multicolumn{1}{c}{ Ders Kitabı Adı } & $\begin{array}{c}\text { Basım } \\
\text { Y1lı }\end{array}$ & Editör \\
\hline $\begin{array}{l}\text { Ortaokul ve İmam Hatip Ortaokulu Türkçe Ders } \\
\text { Kitabı-5 }\end{array}$ & 2018 & $\begin{array}{c}\text { Dr. Öğr. Üyesi Elif AKTAŞ } \\
\text { Dr. Öğr. Üyesi Bora } \\
\text { BAYRAM }\end{array}$ \\
$\begin{array}{l}\text { Ortaokul ve İmam Hatip Ortaokulu Türkçe Ders } \\
\text { Kitab1-6 }\end{array}$ & 2018 & $\begin{array}{c}\text { Doç. Dr. Zekerya BATUR } \\
\text { Sabri CEYLAN }\end{array}$ \\
$\begin{array}{l}\text { Ortaokul ve İmam Hatip Ortaokulu Türkçe Ders } \\
\text { Kitab1-7 }\end{array}$ & 2018 & Nurcihan DEMİRER \\
$\begin{array}{l}\text { Ortaokul ve İmam Hatip Ortaokulu Türkçe Ders } \\
\text { Kitab1-8 }\end{array}$ & 2018 & Doç. Dr. İlhan ERDEM \\
\hline
\end{tabular}

2. Bilişsel ve üstbilişsel işlevlerin tespiti için literatür incelenmiş, belirlenen ölçütler için uzman görüşüne başvurulmuştur. Bilişsel işlevler belirlenirken her düzeyin içerdiği ürün ve hedefler de alt işlev olarak kabul edilmiştir. Bunun yanı sıra sınıflama işlevinin hem analiz düzeyinde hem de kavrama düzeyinde bir beceri olması sebebiyle bulgular kısmında hangi düzeye ait olduğu ayrıca belirtilmiş temelde ise kavrama düzeyine ait bir alt beceri olarak kabul edilmiştir.

\section{Araştırmanın çalışma grubu}

Araştırmanın çalışma grubunu Ankara ili merkez ilçelerinde görev yapan ortaokul Türkçe öğretmenleri oluşturmuştur. Araştırmaya katk1 sunan öğretmen sayıs1 12 olmuştur. Öğretmenlerin 10'u kadın, 2'si erkektir. Öğretmenlerin meslekî deneyimleri göz önüne alındığında, çoğunun 8-10 yıllık çalışma deneyimine sahip olduğu belirlenmiştir. Öğretmenlerin 11'i lisans mezunu 1'i ise doktora mezunudur.

\section{Veri toplama araçları}

$\mathrm{Bu}$ çalışmada üç adet veri toplama aracı kullanılmıştır: Standartlaştırılmış açık uçlu görüşme soruları, uzman görüşü alınarak hazırlanmış bilişsel ve üstbilişsel işlevler ölçütü ve doküman analizidir.

Bu çalışmada doküman analizi, ölçüt örneklemesi, standarlaştırılmış açık uçlu görüşme sorularıolmak üzere 3 adet veri toplama aracı kullanılmıştır. Bu da çalışmanın inandırıcılı̆̆ını güçlendiren bir etmen olmuştur. Çalışmaya başlangıç tarihi 2018 Haziran ayı olmuştur. Geçen 1 y1llık süre içinde veriler tüm yönleriyle analiz edilmeye çalışılmış, 12 öğretmenle görüşme yapılmış etkin katılım sağlanmıştır. Öğretmenlerle yapılan görüşme ise ortalama 25 dakika gibi uzun bir süreyi kapsamıştır. Onlardan alınan cevaplar içerik analizi ile çözümlenmiştir. Bu stratejinin uygulanması da veriye yönelik bir kaybın olmamasını sağlamış bunun yanında verilerin analiz kısmında derinleşmeyi beraberinde getirmiştir. Çalışma boyunca araştırmaya yönelik araştırmacının herhangi bir müdahalesi olmamış, önyargıları, dünya görüşü ve algısı çalışmaya yansımamıştır, bu konuda sık sık özeleştiri yoluna gidilmiştir. Özellikle bilişsel ve üstbilişsel ölçütlerin belirlenmesi aşamasında ve değerlendirilmesi kısmında alanında uzman kişilerden yardım alınmış, onlardan bilimsel olarak görüşleri istenmiştir. Bu sayede hazırlanan ölçütlerin ve dolayısıyla ortaya çıkan sonuçların inandırıcılığıgüçlendirilmiştir. Çalışma kapsamında yapılan geniş tanımlamalar ve kavramsallaştırmalar, bundan sonraki çalışmalarda da bu kavramlar kullanılabilir olasılı̆̆ından hareket edilerekçeşitlendirilmiş ve detaylandırılmıştır. $\mathrm{Bu}$ da çalışmadaki ölçütlerin ve sonuçların bir başka çalışmaya 
aktarılabilirliğini artıran etmen olmuştur. Doküman analizi yolu ile ders kitaplarında bahsi geçen tüm işlevlere dair birden fazla örnek seçilmiş ve incelenmiştir. Bu azami çeşitlilik sayesinde çalışma sırasında elde edilen verilerden yola çıkılarak ortaya konulan bulgular, kayba uğramaksızın ve çok yönlü bir değerlendirme ile oluşturulmuştur. $\mathrm{Bu}$ sayede çalışmanın aktarılabilir olma yönü güçlendirilmişve buradaki bilimsel çıktılar farklı alanlarda kullanılabilecektir.

Tablo 2.

Bilişsel ve Üstbilişsel İşlevler Ölçütü

\section{Bilişsel İşlevler \\ 1. Hatırlama \\ 1.1. Siralama/Suraya Koyma/Siraya Dizme}

\section{Kavrama}

2.1. Sinıflama/Sinıflamak/Sinıflama Yapmak

2.2. Gruplandirma/Gruplandırmak

2.2.1. Aynı/Benzer/Farklı İliş̧isi Kurma

2.3. Yorumlama

2.4. Özetleme

2.5. Dönüştürme (Çevirme)

2.6. Öteleme (Öncelik Sonralık) /Metin

Tamamlama

2.7. Neden-Sonuç İlişkisi Kurma

3. Uygulama

4. Analiz Etme (Çözümleme)

5. Özgün

Üretim/Düzenleme/Tasarlama/Oluşturma

6. Değerlendirme

\section{Verilerin analizi}

Çalışmada kullanılan veriler, içerik analizi ile kategorize edilmiş ve açıklanmıştır. Zira, içerik analizi, toplanan verilerin derinlemesine analiz edilmesini gerektirir ve önceden belirgin olmayan temaların ortaya çıkarılmasına olanak tanır (Yıldırım ve Şimşek, 2018, s. 239).

\section{Bulgular}

İç içe geçmiş çoklu durum deseni ile hazırlanan bu çalışmada, uzman görüşüne başvurularak hazırlanan ölçüt örnekleme yolu ile belirlenmiş bilişsel işlevlerin Türkçe ders kitaplarındaki metinlerde ne kadar yer aldığına yönelik bulgular Tablo 3 'te gösterilmiştir.

Tablo 3.

Metinlerde Yer Alan Bilişsel İşlevlere İlişkin Bulgular

\begin{tabular}{|c|c|c|c|c|}
\hline Bilişsel İşlevler & 5.Sinif & 6.Sinif & 7.Sinif & 8.Sinif \\
\hline 1. $\quad$ Hatırlama & & & & \\
\hline 1.1. Siralama/Siraya Koyma/Sıraya Dizme & --- & --- & --- & 1 \\
\hline Kavrama & --- & --- & 1 & --- \\
\hline 2.1. Sinıflama/Sinıflamak/Sınıflama Yapmak & --- & --- & --- & --- \\
\hline 2.2. Gruplandırma/Gruplandırmak & --- & --- & --- & --- \\
\hline 2.2.1. Ayn1/Benzer/Farklı İlişkisi Kurma & 1 & --- & --- & --- \\
\hline 2.3. Yorumlama & --- & --- & --- & --- \\
\hline 2.4. Özetleme & --- & --- & 1 & 1 \\
\hline
\end{tabular}

Üstbilişsel İşlevler

(Amaçl1lik)

3. Üstbilişsel Bilgi/ Bilişe Dair Farkındalık (Planlama)

5. Sembolleştirme (Hikaye Haritası)

6. Bilgiyi/Stratejiyi/Yöntemi Özetleme

7. Özdeğerlendirme

8. Özfarkındalık/Özyeterlilik
1. Bilgiyi, Kendini Tanımlama

4. Bilişin Düzenlenmesi 
2.5. Dönüştürme (Çevirme)

2.6. Öteleme (Öncelik Sonralık) /Metin Tamamlama

2.7. Neden-Sonuç İlişkisi Kurma

3. Uygulama

4. Analiz Etme (Çözümleme)

5. Ö̈zün Üretim/Düzenleme/Tasarlama/Oluşturma

6. Değerlendirme

\begin{tabular}{rrrr}
--- & --- & --- & --- \\
--- & --- & --- & --- \\
2 & 2 & 2 & 2 \\
3 & 1 & --- & --- \\
1 & 3 & 3 & 2 \\
2 & 1 & 1 & 1 \\
3 & 3 & 1 & 2 \\
\hline
\end{tabular}

Tablo 3'te yer alan bulgular, Türkçe ders kitaplarındaki bilişsel işlevlerin metin yüzeyinde ya da metnin içinde fakat örtük bir şekilde ne kadar yer aldığını göstermektedir. Buna bağlı olarak metinlerde yer alan işlevler düzenli bir şekilde dağılım göstermemiş, sınıf düzeylerine göre dağınık bir biçimde ders kitaplarında yer almıştır. Uygulama, analiz etme, özgün üretim ve değerlendirme işlevleri tüm sınıf düzeylerinde yer almış bilişsel işlevlerdir. Sinıflama, gruplandırma, yorumlama, dönüştürme, öteleme işlevleri hiçbir sınıf düzeyindeki metnin içinde yer almayan bilişsel işlev olarak tespit edilmiştir. Neden-sonuç ilişkisi kurma, analiz etme, özgün üretim ve değerlendirme işlevleri tüm sınıf düzeylerinde yer alan işlevler olmuştur.

Bilişsel işlevlerin gerçekleştirilmesine yönelik soruların ders kitaplarında ne kadar yer aldığını gösteren bulgular, Tablo 4'te verilmiştir.

Tablo 4.

Metin Altı Sorularında Yer Alan Bilişsel İşlevlere İlişskin Bulgular

\begin{tabular}{|c|c|c|c|c|}
\hline Bilişsel İşlevler & 5.Sinif & 6.Sinif & 7.Sinif & 8.Sinif \\
\hline 1. Hatırlama & & & & \\
\hline Siralama/Siraya Koyma/Siraya Dizme & 3 & --- & --- & --- \\
\hline Kavrama & 1 & --- & --- & --- \\
\hline Sinıflama/Sinıflamak/Sinıflama Yapmak & --- & --- & --- & --- \\
\hline Gruplandırma/Gruplandırmak & 1 & --- & --- & --- \\
\hline 2.2.1. Aynı/Benzer/Farklı İlişkisi Kurma & 6 & 3 & 6 & 8 \\
\hline 2.3. Yorumlama & 1 & --- & --- & --- \\
\hline Özetleme & 1 & 6 & 17 & 8 \\
\hline Dönüştürme (Çevirme) & 4 & 5 & 10 & 3 \\
\hline Öteleme (Öncelik Sonralık) /Metin Tamamlama & 8 & 6 & 7 & 1 \\
\hline Neden-Sonuç İlişkisi Kurma & 1 & --- & --- & --- \\
\hline Uygulama & 4 & 3 & 4 & 8 \\
\hline Analiz Etme (Çözümleme) & 9 & 4 & 10 & 2 \\
\hline Özgün Üretim/Düzenleme/Tasarlama/Oluşturma & 39 & 55 & 32 & 49 \\
\hline Değerlendirme & 7 & 1 & 12 & 16 \\
\hline
\end{tabular}

Tablo 4'te Türkçe ders kitaplarında metin altı sorularında yer alan bilişsel işlevlere ilişkin bulgular yer almıştır. Buna göre, sınıflama işlevi hiçbir sınıf düzeyindeki metin altı sorularında yer almamıştır. En az sayıdaki işlev kavrama, yorumlama ve neden sonuç ilişkisi kurma işlevi olmuştur. En fazla metin altındaki sorularda yer alan işlev özgün üretim işlevi olmuştur. Sıralama, kavrama, neden sonuç ilişkisi kurma, gruplandırma işlevi yalnızca 5. sınıf düzeyinde yer almış bir işlevdir. Bilişsel yük anlamında Tablo 4 ile ilgili yapılacak olan genel yorum, bilişsel işlevlerin eşit bir biçimde sınıf düzeylerine dağıtılmadığıdır.

Çalışmada elde edilen ikinci ana bulgu, Türkçe ders kitaplarındaki üstbilişsel işlevlerin metinlerde ve metin altı sorularında ne kadar yer aldığını ortaya koyan bulgudur.Tablo 5'temetinlerde yer alan üstbilişsel işlevlere ilişkin bulgular şu şekilde gösterilmiştir: 
Tablo 5.

Metinlerde Yer Alan Üstbilişsel İşlevlere İlişkin Bulgular

\begin{tabular}{lcccc}
\hline Üstbilişsel İşlevler & 5.Sınıf & 6.Sınıf & 7.Sınıf & 8.Sınıf \\
\hline 1. Bilgiyi, Kendini Tanımlama & 2 & 1 & 1 & 1 \\
2. Üstbilişsel Bilgi/ Bilişe Dair Farkındalık(Amaçlılık) & --- & 1 & --- & --- \\
3. Üstbilişsel Bilgi/ Bilişe Dair Farkındalık(Planlama) & 1 & --- & --- & --- \\
4. Bilişin Düzenlenmesi & --- & --- & --- & --- \\
5. Sembolleştirme (Hikaye Haritası) & --- & --- & --- & --- \\
6. Bilgiyi/ Stratejiyi/ Yöntemi Özetleme & --- & --- & --- & --- \\
7. Özdeğerlendirme & --- & --- & --- & 1 \\
8. Özfarkındalık & --- & --- & --- & 1 \\
9. Özyeterlilik & --- & --- & --- & --- \\
\hline
\end{tabular}

Tablo 5'te görüldüğü üzere 9 işlevin yalnızca 4 tanesi ders kitaplarındaki metinlerde yer almıştır. Bununla birlikte üstbilişsel bilgi (amaçlılık), üstbilişsel bilgi (planlama), özfarkındalık ve özdeğerlendirme işlevleri yalnızca bir sınıf düzeyinde (6.5. ve 8. sınıf) ve 1'er metnin içinde yer almıştır. Tüm sınıf düzeylerindeki ders kitaplarında yer alan işlev, bilgiyi, kendini tanımlama işlevi olmuştur. Bilişin düzenlenmesi, sembolleştirme, bilgiyi özetleme, özfarkındalık işlevleri metinlerde hiç yer almamıştır.

Tablo 6'da metin altı sorularında yer alan üstbilişsel işlevlere ilişkin sonuçlar şu şekilde gösterilmiştir:

Tablo 6.

Metin Altı Sorularında Yer Alan Üstbilişsel İşlevlere İlișkin Bulgular

\begin{tabular}{lcccc}
\hline Üstbilişsel İşlevler & 5.Sınıf & 6.Sınıf & 7.Sınıf & 8.Sınıf \\
\hline 1. Bilgiyi, Kendini Tanımlama & --- & --- & --- & --- \\
2. Üstbilişsel Bilgi/ Bilişe Dair & --- & 1 & --- & --- \\
$\begin{array}{l}\text { Farkındalık(Amaçlılık) } \\
\text { 3. Üstbilişsel Bilgi/ Bilişe Dair }\end{array}$ & 1 & 3 & --- & \\
Farkındalı(Planlama) & Tüm & Tüm & Tüm & Tüm \\
& Hazırlık & Hazırlık & Hazırlık & Hazırlık \\
4. Bilişin Düzenlenmesi & Çalışması & Çalışması & Çalışması & Çalışması \\
& Soruları & Soruları & Soruları & Soruları \\
5. Sembolleştirme (Hikaye Haritası) & 2 & 1 & 1 & --- \\
6. Bilgiyi/Stratejiyi/Yöntemi özetleme & 1 & --- & --- & --- \\
7. Özdeğerlendirme & --- & --- & 5 & 7 \\
8. Özfarkındalık & --- & --- & --- & 1 \\
9. Özyeterlilik & --- & --- & --- & --- \\
\hline
\end{tabular}

Tablo 6'da görüldügü üzere ders kitaplarında metin altı sorularında en fazla yer alan işlev bilişin düzenlenmesi işlevi olmuştur. Sembolleştirme işlevi ise bilişin düzenlenmesi işlevinden sonraki 3 sınıf düzeyinde en sık yer alan işlev olarak tespit edilmiştir. Bilgiyi tanımlama ve özyeterlilik işlevi ise ders kitaplarında metin altı sorularında hiç yer almamıştır. Üstbilişsel bilgi (amaçlılık) ile özfarkındalık işlevi yalnızca 1'er etkinlikte yer alan işlev olmuştur.

Çalışmanın üçüncü sac ayağında yer alan bulgular ise öğretmenlerin bilişsel ve üstbilişsel işlevlere yönelik görüşleri olmuştur. Standartlaştırılmış açık uçlu görüşme soruları ile elde edilen verilere ilişkin bulgular Tablo 7'de düzenlenmiştir. 
Tablo 7.

Öğretmen Görüşlerine İlişkin Bulgular

\begin{tabular}{|c|c|c|c|c|c|c|}
\hline Öğretmen Görüşleri & K1 & $\mathrm{K} 2$ & K3 & K4 & $\mathrm{K} 5$ & K6 \\
\hline Bilişe dair ön bilgim var/yok & Yok & Var & Var & Var & Var & Var \\
\hline Üstbilişe dair ön bilgim var/yok & Yok & Yok & Yok & Yok & Var & Var \\
\hline Üstbilişsel kavramları biliyorum & Evet & Evet & Evet & Evet & Evet & Evet \\
\hline $\begin{array}{l}\text { Üstbilişsel kavramları öğretirken } \\
\text { yöntem kullanıyorum }\end{array}$ & Hayır & Hayır & Hayır & Hayır & Evet & Hayır \\
\hline $\begin{array}{l}\text { Metin altındaki soruları bilişsel } \\
\text { basamaklarla ilişkilendiriyorum }\end{array}$ & Hayır & Hayır & Hayır & Hayır & Evet & Evet \\
\hline $\begin{array}{l}\text { Üstbiliş̧e dair işlevlerin gelişmesi } \\
\text { için model oluşturuyorum }\end{array}$ & Hayır & Hayır & Hayır & Hayır & Hayır & Evet \\
\hline $\begin{array}{l}\text { Üstbilişsel bilginin öğretimi için } \\
\text { hangi stratejileri kullanıyorsunuz? }\end{array}$ & $\begin{array}{l}\text { Tekrar } \\
\text { okuma }\end{array}$ & $\begin{array}{l}\text { (Amaçli) } \\
\text { soru } \\
\text { sorma }\end{array}$ & Tartışma & --- & --- & $\begin{array}{l}\text { İpucu } \\
\text { ve soru } \\
\text { sorma }\end{array}$ \\
\hline Ön hazırlık yapıyor musunuz? & Evet & Evet & Evet & Evet & Evet & Evet \\
\hline $\begin{array}{l}\text { Soru sorarken taksonomiyi } \\
\text { dikkate alıyor musunuz? }\end{array}$ & Evet & Evet & Evet & Evet & Evet & Evet \\
\hline $\begin{array}{l}\text { Öğrenci metni anlamadığında bu } \\
\text { durumla ilgili saptamada } \\
\text { bulunuyor musunuz? }\end{array}$ & Evet & Evet & Evet & Evet & Evet & Evet \\
\hline $\begin{array}{l}\text { Metinleri çok boyutlu } \\
\text { değerlendiriyor musunuz? }\end{array}$ & Hayır & Evet & Hayır & Hayır & Evet & Hayır \\
\hline
\end{tabular}

Tablo 7.

Öğretmen Görüşlerine İlişkin Bulgular - Devamı

\begin{tabular}{|c|c|c|c|c|c|c|}
\hline Öğretmen Görüşleri & K7 & K8 & K9 & K10 & K11 & K12 \\
\hline Bilişe dair ön bilgim var/yok & Yok & Var & Var & Var & Var & Var \\
\hline $\begin{array}{l}\text { Ustbilişe dair ön bilgim } \\
\text { var/yok }\end{array}$ & Yok & Yok & Yok & Var & Yok & Yok \\
\hline $\begin{array}{l}\text { Üstbilişsel kavramları } \\
\text { biliyorum }\end{array}$ & Evet & Evet & Evet & Evet & Evet & Hayır \\
\hline $\begin{array}{l}\text { Üstbilişsel kavramları } \\
\text { ögretirken yöntem } \\
\text { kullanıyorum }\end{array}$ & Hayır & Hayır & Evet & Hayır & Hayır & Hayır \\
\hline $\begin{array}{l}\text { Metin altındaki bilişsel } \\
\text { basamaklarla } \\
\text { ilişkilendiriyorum }\end{array}$ & Hayır & Hayır & Evet & Evet & Hayır & Hayır \\
\hline $\begin{array}{l}\text { Üstbilişe dair işlevlerin } \\
\text { geliş̧mesi için model } \\
\text { oluşturuyorum }\end{array}$ & Hayır & Hayır & Hayır & Evet & Hayır & Evet \\
\hline $\begin{array}{l}\text { Üstbilişsel bilginin öğretimi } \\
\text { için hangi stratejileri } \\
\text { kullanyorsunuz? }\end{array}$ & $\begin{array}{l}\text { Not alma, } \\
\text { yeniden } \\
\text { yazma }\end{array}$ & $\begin{array}{l}\text { Tartışma } \\
\text { ve soru } \\
\text { sorma }\end{array}$ & $\begin{array}{l}\text { Soru } \\
\text { sorma }\end{array}$ & $\begin{array}{l}\text { Yöntemi } \\
\text { tanımlama }\end{array}$ & $\begin{array}{l}\text { Soru } \\
\text { cevap }\end{array}$ & $\begin{array}{l}\text { Soru } \\
\text { cevap }\end{array}$ \\
\hline Ön hazırlık yapıyor musunuz? & Evet & Evet & Evet & Evet & Evet & Evet \\
\hline $\begin{array}{l}\text { Soru sorarken taksonomiyi } \\
\text { dikkate alıyor musunuz? }\end{array}$ & Evet & Evet & Evet & Evet & Evet & Evet \\
\hline $\begin{array}{l}\text { Öğrenci metni anlamadı̆̆ında } \\
\text { bu durumla ilgili saptamada } \\
\text { bulunuyor musunuz? }\end{array}$ & Evet & Evet & Evet & Evet & Evet & Evet \\
\hline
\end{tabular}


Metinleri çok boyutlu değerlendiriyor musunuz?

Hayır Evet Evet Evet Evet Evet

Tablo 7'de görüldüğü üzere öğretmenlerin $(n=10)$ bilişe dair ön bilgilerinin olduğu görülmektedir. Öğretmenlerin $(n=9)$ üstbilişe dair ön bilgilerinin olmadığ1 tespit edilmiştir. Öğretmenler $(\mathrm{n}=11)$ üstbilişe dair kavramları bildiğini ifade etmiştir. Öğretmenlerin yarısının $(n=6)$ üstbilişsel kavramları öğretirken yöntem kullandığı, diğer yarısının ise $(n=6)$ kullanmadığ tespit edilmiştir. Öğretmenlerin $(\mathrm{n}=8)$ metin altındaki soruları bilişsel basamaklarla ilişkilendirmediği tespit edilmiştir. Öğretmenlerin $(n=9)$ üstbilişsel işlevlerin gelişmesi için model oluşturmadıkları belirlenmiştir. Öğretmenlerin $(n=6)$ üstbilişsel bilginin öğretimi için soru-cevap tekniğini kullanmayı tercih ettiklerini söylemişlerdir.

Öğretmenlerin tamamı $(\mathrm{n}=12)$ dersle ilgili ön hazırlık yaptıklarını ifade etmişler ve bunu ders öncesi hazırlık olarak yorumlamışlardır. Bununla birlikte öğretmenlerin tamamının soru sorarken bilişsel taksonomiyi dikkate aldığ belirlenmiştir. Fakat bu veri, öğretmenlerin "metin altındaki soruları bilişsel basamaklarla ilişkilendirmiyorum" yanıtlarıyla çelişmektedir, zira o soruya "evet" diyenler $(\mathrm{n}=8)$, "soru sorarken bilişsel taksonomiyi dikkate alıyorum" yanıtıyla $(n=12)$ içsel bir tutarsızlık oluşturmuştur. Öğretmenlerin tamamı $(n=12)$ öğrencilerin metni neden anlamadığına dair üstbilişsel saptamalar yapmaktadır. Öğretmenlerin $(n=5)$ metinleri çok boyutlu değerlendirmedikleri ortaya çıkmış, onlar bunun belirleyicisinin hedef kitle olduğunu belirtmişlerdir. Fakat büyük bir kısmı $(n=7)$ yine de metinleri çok boyutlu değerlendirdiğinisöylemiştir.

\section{Tartışma, Sonuç ve Öneriler}

Bu çalışmanın neticesinde Türkçe ders kitaplarında tespit edilen bilişsel işlevler ile ilgili ulaşılan sonuçlar şu şekildedir:

Sıralama işlevi 5., 6. ve 7. sınıf düzeylerindeki ders kitaplarında metin içinde açık ya da örtük bir biçimde yer almamış, ana metne dayalı ya da ana metinden bağımsız bir şekilde ölçme değerlendirmeye tabii tutulan beceri olmuştur. Sıralama kavramı çoğunlukla kavrama becerisinin ölçülmesinde kullanılan bir beceri olarak tercih edilmiş, en çok olay örgüsü ile ilgili kavramanın ölçülmesinde kullanılmış, bu şekilde zaman kavramının çizgisel ilerleyişi bir sağlamaya tabii tutularak ölçülmüştür. Bu beceri yalnızca 8 .sınıf düzeyindeki bir metinde açık bir biçimde yer almış, temel işlevini (hiyerarşi) yerine getirmiştir.

Sınıflama işlevi, tüm sınıf düzeylerindeki ders kitaplarında taranmış ve bu kavram hem açık hem de örtük bir biçimde metinlerde ya da metin altı sorularında tespit edilememiştir. Burada bahsi geçen sınıflama kavramı salt "genelleme ve ayırt etme" kavramları etrafinda oluşan bir beceri bağlamında değerlendirilmiş, analiz becerisinin yan unsuru olarak düşünülmemiştir. Zira analiz becerisinin yan unsuru olarak "kategorize etme" anlamında birçok yerde tespit edilmiştir. Fakat temel işlevini yansıtacak şekilde metin içinde ve metin altında yer alan sorularda yer almamıştır.

Gruplandırma işlevi, ders kitaplarının tümü incelendiğinde metinlerin içinde açık bir biçimde yer almamıştır. Ders kitapları bu kavramın yalnızca alt bileşenlerini (aynılık, benzerlik ve farklılık) ihtiva etmiştir. Bu kavramlar, metin içinde art gönderim amaçlı kullanılmış, metin altında yer alan sorularda ise "kavrama" becerisini ölçecek nitelikte kullanılmıştır. Gruplandırma becerisi, metin türlerini ayırt etme etkinliklerinde tercih edilmiştir, ilginç olan şu ki sınıflama becerisi bu konuda daha işlevsel iken o işlevden bu konuda hiç yararlanılmamıştır. Etkinlik düzeyine yansıyan tek örnek 5. sınıf ders kitabında tespit edilmiştir.

Yorumlama işlevi, ana fikir ve yardımcı fikir bulma etkinliği olarak kitaplarda yer almıştır. Bu beceri, kazanımın etkinliğe dönüştüğü bir beceridir. Çoğunlukla hazırlık soruları ve metin altı soruları içerisinde ölçme değerlendirmeye tabii tutulmuş bir beceri türüdür. Bunun dışında metin içi bir kullanım söz konusu olmamış, metinden ya da görselden hareketle bu beceri ölçülmüştür. Becerinin öğretimine, yöntemine ve basamaklarına ilişkin bir bilgi metin içinde yer almamıştır. 
Özetleme işlevi, ders kitaplarında özetleme kazanımının etkinlik olarak algılanması suretiyle öğrenciden bu bilişsel yükü ağır olan beceri, her seferinde tüm süreçleri işletecek şekilde istenmiştir. Özetleme süreç gerektiren bir beceri olmasına rağmen ders kitapları sonuca dönük ve süreçleri öğrenciye kazandırmadan bir ölçme değerlendirme metodu benimsemiştir. 7 . sınıf (2) ders kitabında tespit edilen özetleme kavramı, yalnızca tek bir metnin içinde ve "kısacası, sonuç itibariyle" anlamını yansıtacak şekilde kullanılmıştır.

Dönüştürme-Çevirme işlevi, öğretim programında matematiksel bir yetkinlik (MEB Öğretim Programı, 2018:5) ve bilim/teknolojide temel yetkinlik olarak tanımlanmıştır. Öğretim programında buna yer verilmesi ile birlikte ders kitaplarının bu noktada içeriği grafikler, tablolar, zihin ve kavram haritaları ile oluşturulmuştur. Fakat bu beceri metinler ile süreç içinde geliştirilmesi gereken bir beceriden ziyade sonuç odaklı ve metinden bağımsız uygulama örnekleri olarak ders kitaplarında yer almıştır. Ders kitabında yer alan bu beceri, sıklıkla "metin türünü dönüştürme" ve "metin içi karakterin dönüştürülmesi" noktasında kendini göstermiştir. Görseli metne dönüştürme, dinlediğini görsele dönüştürme, anlatıcıyı dönüştürme, (I. tekilden III. tekile vs.) karakteri dönüştürme (empatik dönüştürme) tercih edilen dönüştürme türleri olmuştur. Metnin bir veri kaynağı olarak tasarlanması, o verilerden yola çıkılarak herhangi bir tablo, grafik hazırlama yoluna gidilmemiştir.

Metin tamamlama işlevi, en fazla yazma becerisini örnekleyen etkinlikler şeklinde ders kitaplarında yer alan bir beceri türü olmuştur. İlginç bir biçimde diğer 3 dil becerisini kapsayacak hiçbir örnekte bu işleve yer verilmemiştir. Metin tamamlama örnekleri kavrama becerisinin çok ötesinde özgün yaratımı ortaya koyan yani bilişsel yükü daha fazla olan örnekler olarak tasarlanmıştır. Zira, öğretim programında yer alan kazanımları karşılama amacı, öğretimin çok önüne geçmiştir. $\mathrm{Bu}$ becerinin omurgasını oluşturan bağlantı ifadelerini kullanır,kazanımı kitapta yer alsın diye her seferinde metin tamamlama etkinliği ile öğrenci karşı karşıya bırakılmıştır. Üst düzey bilişsel bir beceri, her sınıf düzeyinde bilişsel yükü az olan bir beceri olarak varsayılmış bu sebeple de ilk metinden son metne kadar tüm sınıf düzeylerinde yer alan metinlerde ölçme aracı olarak kullanılmıştır. Bunun yanı sıra düzensiz bir bilişsel yük dağılımı da bu işlevle ilgili örnekler üzerinden açıkça gösterilebilir, örneğin: 5 . sınıf düzeyinde 8 metin tamamlama, 6. sinıf düzeyinde 6 metin tamamlama, 7. sinıf (1) düzeyinde 1 metin tamamlama, 7. sinıf (2) düzeyinde 6 metin tamamlama, 8. sinıf düzeyinde 1 metin tamamlama örneği tespit edilmiştir. Nicel açıdan bir oran problemi açık bir biçimde kendini göstermektedir. Bu da öğretim programının sistematik yapısı ile çeliş̧i oluşturmuştur.

Neden-sonuç ilişkisi kurma işlevi, ders kitaplarında, çoğunlukla ana fikri sunma ya da metinde yer alan vakanın genişlemeye başladığı noktada kullanılmış, bir bakıma kahraman için peripeteia (baht dönüşümü) durumunu sağlayan bir işlev olarak kendini göstermiştir. Bu işlev en çok bilgilendirici metin türlerinde kullanılmış (metnin iletisinin merkezini oluşturmuştur), tahkiye türündeki metinlerde ise ana fikri ve yardımcı fikirleri bir önerme olarak sunarken bu işlevden yararlanılmıştır. Bu işlev öğretim programında kazanımın altında bir not olarak geçtiği için sıklıkla açık bir şekilde neden sonuç ilişkisi kurmaya dönük sorular şeklinde metinlerin altında yer almıştır. "Dinledikleri/izledikleri/okudukları hakkında çıkarımlarda bulunur." (MEB Öğretim Programı, 2018, s. 33, 38, 42, 46) kazanımının alt ögesi olarak tanımlanan bu işlev, en çok bu kazanımı destekleyen nitelikte kullanılmıştır.

Uygulama işlevi, ders kitaplarının tümünde dil bilgisi ile ilgili konuların tatbik edilmesi olarak algılanmış bir işlevdir. Bu bağlamda ders kitapları incelendiğinde uygulama becerisi tüm seviyelerdeki ders kitaplarında ölçme değerlendirme için bir araç olarak düşünülmüştür. $\mathrm{Bu}$ beceri ders kitaplarında metinden etkinliğe tam anlamıyla yansıyan becerilerin başında gelmektedir. Uygulama becerisinin alt kategorileri, noktalama işaretlerine göre metni okuma, bir şiir örneğine benzer yeni şiir yazma, bir probleme dönük ilke ve kriter seçme gibi unsurlar olarak tespit edilmiştir. Her metnin başında noktalama işaretlerine uygun okuyunuz gibi örnekler yahut öğretilen bir dil bilgisinin tatbikine uygun etkinlik örnekleri sıklıkla karşılaşılan uygulamalar olmuştur.

Analiz etme-çözümleme, alt-üst kategorizasyon işlevi, bu bilişsel işlev ders kitaplarında sıklıkla metin türleri arasındaki farkı ortaya koyacak şekilde tasarlanmış ve etkinlikler 
aracıllğıyla verilmiştir. Gözlem ve görselden yola çıkılarak yapılan çıkarımlar metin içinde yer alan analiz becerisi örneklerinin temelini oluşturmuştur. Analiz becerisinin alt kavramını oluşturan kategorize etme becerisi ya da alt-üst kategori arasındaki ilişkiyi tanımlama ve kurmaya dönük beceriler, en çok bilgilendirici metin türleri içinde yer almış ve bu metinlerin altında tasarlanan etkinliklerde uygulanmıştır. İkinci olarak ölçülen analiz becerisi alt grup becerileri ise, beden diline ait çözümlemelerin yer aldığg pasajlar ve etkinlikler örnekleri ile metinde yer alan kişilerin fiziksel ve psikolojik özelliklerinin kategorizasyonu üzerine inşa edilen etkinlik örnekleri olmuştur. Bunun yanında tahkiye türündeki metinler duygu analizi, psikolojik analiz, beden dili analizi, eylem analizi gibi uygulamaları içinde barındıran metin türü olarak tespit edilmiş, bilgilendirici metinler ise kavramsal kategorizasyonu içeren metin türü olarak belirlenmiştir.

Özgün üretim, modelleme işlevi, bu bilişsel işlev sonuç odaklı bir ölçme aracı olarak kullanılmış ve ders kitaplarında nicel olarak ilk sırada yer alan beceri olmuştur (5.sınıf, 39, 6.sınıf, 55, 7.sınıf 32, 8.sinıf 50 adet özgün üretim etkinliği). En sık başvurulan yöntem, metin tamamlama yolu ile özgün metin üretimidir. Ancak bu metinler şeklen özgünlük taşımayan (metin türü sabit kalmakta) içerik açısından özgün üretime dönük uygulamalardır. Ayrıca, kazanımın en çok etkinliğe dönüştüğü bilişsel işlevlerden biri de özgün yaratma(üretim) işlevi olmuştur, örneğin: İzlediklerine/ Dinlediklerine farklı başlıklar önerir (MEB Öğretim Programı, 2018, 48, 44, 40, 36) kazanımı direkt etkinliğe dönüşmüş, öğrenciye bu üretim için herhangi bir yöntem bilgisi verilmemiştir. Bunun dişında, şiir yazar, kısa metin yazar, hikaye edici metin yazar vs. (MEB Öğretim Programı, 2018: 43, 42, 39) gibi kazanımlar da yine etkinlik olarak karşımıza çıkan ama doğası gereği sonuç odaklı bir ölçme değerlendirmeyi içerisinde barındıran örneklerdir. Metin tamamlama yolu ile özgün metin üretimi, üretme becerisinin kilit noktas1 olmuştur. Buna istinaden diğer özgün tasarı biçimleri ise şunlar olmuştur: Kavram üretimi, özgün görsel tasarım, özgün slogan üretimi, özgün materyal tasarımı, özgün proje tasarlama (probleme dönük). Ve fakat hepsinde nihai bir ölçme, yöntem ve teknikten uzak, bilişsel yükün düzeylere göre uygun dağıtılmadığı örnekler ortaya konmuştur.

Değerlendirme işlevi, bu işlev tüm sınıf düzeylerinde tespit edilmiştir. Daha çok etkinlik olarak tercih edilen bu beceri, soru kökünde verilen kritere göre değerlendirme, metnin içinden kriter bulma ve kritere yönelik eleştiriler şeklinde işlevini yerine getirmiştir.

Çalışmanın ikinci ayağında ders kitaplarındaki metinlerde ve metin altı sorularında incelenen işlevler üstbilişsel işlevler başlığını oluşturmuştur. Bu bağlamda ders kitaplarındaki üstbilişsel işlevler ile ilgili şu sonuçlara ulaşılmıştır:

Bilgiyi (kendini) tanımlama işlevi, ders kitaplarında en çok tahkiye türü metinlerde görülmüş, ikinci sırada ise bilgilendirici metin türlerinden deneme metinleri içinde kullanılmıştır. Metin altında yer alan soruların tüm sınıf düzeyleri incelendiğinde hiçbirinin bu işlevi aktif hale getirebilecek herhangi bir yönerge sunmadığ belirlenmiştir. Bununla beraber "ben" kavramının baskın olduğu metinlerin büyük kısmı bu işlevi yerine getirecek türdeki metinler olarak yorumlanmıştır. Ve fakat metinlerin büyük kısmında bu işlev örtük bir ögretim metodu yolu ile kendine yer bulmuştur.

Bilişe dair farkındalık işlevi, bu işlevin alt işlevleri amaçlılık, planlama ve bilgiyi özetleme işlevi olarak tespit edilmiştir. Amaçlılık işlevi, otobiyografik anlatıyı benimseyen bir metinde (6. sınıf) ve süreç planlaması yaparken bilişsel amaçların sıralanmasını örnekleyen bir metnin içinde tespit edilmiştir. Planlama işlevi, ders kitaplarında soru sorma yolu ile metin tasarlama biçiminde kendine yer bulmuş bir işlevdir. Ders kitabı metne ait yapısal unsurları kavratmak için bu üstbilişsel işlevi bir teknik olarak sıklıkla kullanma yoluna gitmiştir.

Özetleme işlevi bu işlev yalnızca bilişe ait değil aynı zamanda üstbilişe ait bir işlev olarak belirlenmiştir. Üstbilişsel anlamda değerlendirilmesinin sebebi, ders kitabı içindeki bir örnek üzerinden örtük bir strateji öğretiminin gerçekleştirilmesi ve özetleme becerisini stratejik olarak kullanmayı gerektiren bir uygulamayı içinde taşıması olmuştur. Fakat bu becerinin stratejik anlamda öğretimi açık bir biçimde olmamış, bu strateji becerisi, örtük bir ölçmeye tabii tutulmuş 5. sınıf düzeyinde bir kez kullanılmış ve diğer sınıf düzeylerinde bir daha uygulanmamıştır. 
Bilişin düzenlenmesi işlevi, bu işlev tüm ders kitaplarında tespit edilmiş ve hepsinde yer almış bir işlevdir. Zira, bu işlevin bulunduğu alan, tüm hazırlık sorularıdır.

Özdeğerlendirme işlevi, Türkçe ders kitapları, özdeğerlendirme kavramını yalnızca ölçme değerlendirme formu olarak benimsemiş, metinlerin bu işlevi doğrudan yerine getirebilecek bir araç olduğu perspektifini göz ardı etmiş, bu beceriyi soru ve madde köklerine sıkıştırmış, metin aracılığıyla öğrencinin bu beceriye ilişkin farkındalığının gelişebileceğini dikkate almamıştır. Daha ilginç olanı ise bu ölçme yöntemi 7.sınıfa kadar ders kitabı içinde kendine yer bulamamıştır. 7 ve 8.sınıf düzeyleri dışında tespit edilemeyen bu beceriye ilişkin herhangi bir öğretim ve ölçme uygulaması yapılmadan blok bir biçimde yalnızca iki sınıf düzeyinde öğrencinin muhatap olduğu bu durum, öğretim programının ruhuna aykırı bir portre çizmektedir. Ders kitapları, ölçme değerlendirme yaklaşımı olarak benimsenen bu yapıyı metne dahil etmemiştir, yalnızca formlar üzerinden değerlendirme yoluna gitmiştir. Bu formların hiçbirinin adı ders kitaplarında özdeğerlendirme formu olarak yer almamıştır.

Özfarkındalık ve özyeterlilik işlevine ilişkin sonuçlar. Ders kitapları incelendiğinde özfarkındalık kavramı hiçbir sınıf düzeyinde ve hiçbir metinde açık bir biçimde kendine yer bulamamıştır. Sıklıkla metin içinde yaratılan kişinin iç muhakemesine tanık olunabilecek pasajlara yer verilmiş veyahut bilinçli bir biçimde olmasa da metin altı sorular yoluyla öğrenciye kendi farkındalık düzeyine yönelik ölçme değerlendirme uygulamaları sunulmuştur. Bu beceriyi somutlayan tek örnek 8. sınıf ders kitabında tespit edilmiş ve yazma becerisi dahilinde bir özfarkındalık durumu ölçülmek istenmiştir. Özyeterlilik becerisi müstakil bir biçimde metinlerin içinde açık ya da örtük bir şekilde yer almamıştır. Özfarkındalık içeren pasajların veya örneklerin içindeki dolaylı, ikincil beceri olarak karşımıza çıkmıştır.

Sembolleştirme ve yüksek sesle düşünme işlevi, bu işlev, okuma anlamaya yönelik sembolleştirme stratejilerinden biri olan hikaye haritası oluşturma, ders kitapları içinde sıklıkla ölçme değerlendirme amacıyla kullanılmış, ancak bu strateji okuma ile birlikte simultane bir biçimde anlamaya dönük kullanılması gereken bir strateji iken ders kitaplarında sonuç odaklı şablon olarak kullanılmıştır. Ders kitaplarında görünen şekliyle, metin okunduktan sonra öğrencinin metni anlama düzeyini ölçmek adına tasarlanmış bir kavram olmuştur. Ders kitapları incelendiğinde "hikaye haritası" kavramının muadili olarak "hikayenin unsurları" kavramı kullanılmıştır. 7. sınıf ders kitabındaki 1 örnek okuma anında hikaye haritası oluşturma stratejisini kullanmaya dönük bir etkinlik olarak tasarlanmıştır. Bu örneğin belki de en önemli özelliği bir strateji olarak tasarlanmış oluşudur. Zira bundan önceki düzeylerde görülen hikaye haritası oluşturma kavramı çoğunlukla sonuç odaklı bir ölçme değerlendirme aracı olarak görevini yerine getirmiştir. Oysa bu örnek okuma anında gerçekleştirildiği için bilişsel anlamda sembol oluşturma ve düşünceyi sembolleştirme üstbilişsel işlevini yerine getirmektedir. Bilişsel anlamda bir problemin tespiti ve çözümü için bilişsel farkındalığı gösteren, metin yapısı itibariyle "yüksek sesle düşünme" stratejisini de yansıtan otobiyografik anlatılar, üstbilişsel strateji olarak tespit edilen ikinci strateji olmuştur.

Öğretim programında yer alan kazanımların bir kısmı bilişsel ve üstbilişsel işlevleri yansıtacak şekilde tasarlanmıştır. Bunlardan en çok karşımıza çıkanı herhangi bir dil becerisi konusunda strateji kullanır ile ilgili kazanımlardır, bunların dışında geriye kalan kazanımlar ise biliş ile ilgili kazanımlardır-özetler, ana fikri/yardımcı fikri bulur vs.-. Fakat programda bilişsel beceriler ile ilgili alt düzey beceriler verilmeden direkt üst düzey becerilere dönük bir öğretim anlayışı benimsenmiştir. Bu sebeple çalışma sonucunda elde edilen bulgular, bilişsel ve üstbilişsel işlevlerin tartışmaya açık noktalarını daha çok öğretim programında yer alma biçimi üzerine yoğunlaştırmıştır.

Öğretim programı biliş kavramı ekseninde değerlendirildiğinde karşımıza çıkan tablo, bu kavramın sıklıkla ölçme değerlendirme odaklı bir anlayışın ürünü olduğu yönündedir. Öğretim programında geçen "üst düzey bilişsel beceriler" kavramı programın özel amaçları başlığ 1 altında değerlendirilmiş ve bu şekilde kitap yazarı için de yol gösterici olmuştur. Ve fakat öğretim programı bunu bir ölçme değerlendirme yaklaşımı olarak belirleyince ders kitabı yazarları da bu becerileri sıklıkla sonuç odaklı ölçme biçimlerine tabii tutmuştur. Oysa ölçülen bir şeyin önce eğitimi verilmeli, yöntemi öğretilmeli ve bu yöntemler de Türkçe dersi özelinde 
düşünülürse metinlere yansıtılmalıdır. Ancak görünen o ki metinlerin birer araç olarak tasarlanıp bu becerileri kendi içlerinde ihtiva etmeleri gerekirken, metinlerin içine açık bir biçimde bahsi geçen ne üst düzey bilişsel ne de "alt düzey" bilişsel becerilerin kavram olarak konulduğu, sürekli olarak yazarın örtük bir öğretim metodu benimsediği görülmüştür. Esasen bu durum bütüncül bakış açısından uzak ve metodik bir perspektifin yokluğunun işaretidir. Zira kazanımlar da bir hiyerarşi ile hazırlandıysa eğer, ki öğretim programı bunu savunmakta-ya da buna düalist demek daha doğru olur- alt/üst, basit/zor, yakın/uzak, benzer/farkl1- o halde yapılması gereken şey, metinler aracılığıyla bu işlevleri yerine getirmek hem de hiyerarşik bir biçimde yerine getirmektir. Öyle ki metinlerin ders kitabında sıralanışından etkinliklerin tasarlanmasına kadar tüm yapılarda, bahsi geçen bu hiyerarşik yöntem kullanılmalıdır. Bu kendi içinde yaşanılan tutarsızlıklar, sonuç itibariyle çalışma boyunca sıklıkla vurgulanmıştır.

Öğretim programı üstbiliş kavramını nihai bir çıktı olarak tasarlamış ve bunu kendine gaye edinmiştir. Fakat ilginç olan şu ki, öğretim programı bunu bazen beceri (MEB Öğretim Programı, 2018, s. 3) bazen de kişisel gelişim (MEB Öğretim Programı, 2018, s. 17) olarak algılamıştır. Beceri olarak algıladığı yerlerde bu kavramı "Yetkinlikler" başlığı altında incelemiş ve bir sonraki aşamada "öğrenmeyi öğrenme" olarak kavramsallaştırmıştır. Bunu yaptıktan sonra, ders kitaplarında yer alacak olan temaları sıralarken, becerileri." Kişisel Gelişim” teması olarak düşünmüş bunları temanın içine giren konular başlığında da konu olarak aktarmıştır. Konu olarak adlandırılan kavramlar "özdenetim, özdüzenleme, kendini tanıma, özeleştiri, özsayg1, özyeterlilik, zaman yönetimi” (MEB Öğretim Programı, 2018, s. 17) gibi üstbilişsel becerilerin tam da kendisidir. Yaşanan bu anlamsal tenakuzlar, belirlenen amaçlar ve yöntemlerin çelişmesi, Türkiye Yeterlilikler Çerçevesi'nde tespit edilen umumi yetkinlikler ve sonra "konu"ya dönüşen kavramlar... Görünen odur ki iç tutarlılığı sağlanamamış bir program sonucunda ortaya konulan ders kitaplarının içinde yer alan metinlerin ve metin altı sorularının hiyerarşik, tutarlı ve bahsi geçen kavramlara hizmet eden, külliyen çalışan bir mekanizma oluşturması söz konusu olamaz.

Çalışma üç sac ayağından oluşan bir yapı sergilemekte olduğu için son nokta öğretmen görüşlerine ilişkin bulgulardan oluşturulan sonuçlardır. Buna göre öğretmen görüşlerine dair sonuçlar şu şekildedir:

Öğretmenlerle yapılan görüşmeler dahilinde elde edilen en önemli sonuç, bu iki kavrama dair öğretmenlerin sahih ve açık bir ön bilgilerinin olmadığıdır. Bu ön bilgi eksikliği 10 yılın üzerinde çalışan öğretmenlerde daha fazla, 10 yılın altındakilerde ise daha azdır. İlaveten, ögrretmenlerin lisans dönemlerinde daha çok biliş kavramı ile karşılaştıkları, alan sınavına çalışırken ise üstbiliş kavramını tanıdıkları tespit edilmiştir. Kavramsal olarak bakıldığında üstbiliş kavramını üst düzey bilişsel beceriler olarak algılamışlar buna yüksek bilgi, beceri gerektiren birtakım bilişsel eylemleri dahil etmişlerdir (Kompozisyon yazma, şiir yazma vs.). Tüm katılımcılar derse bu kavramları açık bir biçimde dahil etmediklerini söylemiş, bu beceri alanlarından yararlanmadıklarını dile getirmişlerdir. Fakat tüm öğretmenlerde tespit edilen şey, bilinçli bir şekilde olmayan sezgisel bir öğretim metodu benimsemiş olduklarıdır. Zira büyük bir kısmı bilişsel taksonomiye göre soru sormasa da hepsi hangi sorunun ne zaman sorulacağına dair bir iç refleks geliştirmiş. Bu refleks ile öğretmenlerin farkında olmadan metne yönelik doğru bir hiyerarşi uyguladıkları görülmüştür. Fakat kavramsallaştırma ve bilinçlilik durumu olmadığ 1 için kullandıkları yöntem ve teknikler temelsiz bir bina inşa etmeye benzemektedir. Öğretmenlerde örtük bir strateji öğretimi eğilimi olmasına rağmen bunları yalnızca örnekler üzerinden tanımladıkları tespit edilmiştir. $\mathrm{Bu}$ da bilinçli bir farkındalığın olmadığını ve içselleştirilmiş bir bilgiden ziyade deneyime dönük zaman içinde gelişen daha ampirik bir öğretim metodu kullandıklarını ortaya koymuştur. Öğretmenlerin son soruya verdikleri yanıt ders kitaplarında yer alan metinlerle ilgili olumsuz görüşlerini yansıtmıştır. Sorunun işlevi estetik süreçlerin farkında olup olmadıklarına yönelik bir durumu ortaya çıkarmakken öğretmenlerin büyük bir kısmı metinlerin zayıf olduğunu dile getirmişlerdir. Üstbilişsel süreçler bireysel merkezli olmasına rağmen öğretmenler bu konu hakkındaki belirleyici tutumlarını derslerine girdikleri sınıfın belirlediğini söylemişlerdir. Kitlenin belirleyici bir unsur olarak düşünülmesi bulgular kısmında verilen "özdeğerlendirme ve 
özeleştiri yaparım hep" şeklindeki cevapla içsel bir çelişki oluşturmaktadır. Bu kavramlar ve kendileri ile ilgili olan durumlarda kitle belirleyici olmazken, esas kitle özne konumunda ve eylemler ona dönükken bir şekilde katalizör görevi sınıfa verilmiştir. Aslında öğretmenlerin repertuarında üstbilişsel stratejiler mevcuttur (Akın ve Abacı, 2011, s. 61). Fakat bilinçli bir modelleme sunmadıkları için gerçekleştirdikleri tüm olumlu ve etkili metotlar sezgisel düzeyde yorumlanacak örnekler olmuştur.

Çalışma sonucunda araştırmacı ve uygulayıcılar için şu önerilerde bulunulmuştur:

1. Araştırmacılar, bilişsel ve üstbilişsel işlevlerin açık bir biçimde kavramsal olarak yer aldığı metinler ile açık bir biçimde bu kavramların yer almadığı metinleri öğrencilere sunabilir, kavramsal olarak bu becerilere dair farkındalık durumlarını ölçebilir. Üstbilişsel stratejiler ile dizayn edilmiş bir metin ile bu şekilde tasarlanmamış bir metin öğrencilere sunulup öğrencilerin okuma- anlama düzeyleri incelenebilir. Araştırmacılar, ben (I. tekil) anlatıcısı ile tasarlanmış bir metinle, o (III. tekil) anlatıcısı etrafında gelișen bir metni öğrencilere sunduğunda öğrencinin üstbilişsel becerilerden hangi metinde daha sık yararlandığını ortaya koyan bir çalışma yapabilir. Metinler için bilişsel ve üstbilişsel işlevler dahilinde bir modelleme yapılabilir. Bununla birlikte öğretim programı hazırlanırken, program, kendi içinde yeterlilik, beceri olarak tanımladığ 1 ögeleri konu ya da tema başlığı altında değerlendirmeden, direkt beceri ve hatta kazanıma dönüşmüş beceri olarak öğretim programına dahil edebilir. Öğretim programında yer alan kazanımların bilişsel yükü sistemli ve gerçekleştirilebilir surette programa yayılmalı ve ders kitabı da aynı metodolojiyi benimseyen bir minvalde tasarlanmalıdır.

2. Ders kitabı hazırlayanlar, her bir bilișsel beceriyi kendi içindeki alt düzey becerilerle ilişkilendirmeli, öğrenciden paket bir biçimde, sonuç odaklı bir beceri istenmemelidir. Örneğin ana fikir, yardımcı fikir bulma gibi kavrama düzeyini içine alan bu temel bilişsel beceri, içindeki alt düzey becerilerin öğretimi gerçekleştirilerek öğrenciye sunulmalıdır. Kazanım şeklinde verilmiş olan beceriler ders kitaplarının içinde etkinlik olarak düşünülmemeli, bunlar açılmalı ve içi doldurulmus, her becerinin gerçekleștirilebilir olduğu öğrenciye yöntem bilgisi verilerek öğretilmelidir. Bunun yanında metinler birer araçken onlardan daha fazla yararlanılmalı, metinden bağımsız salt kazanımı gerçekleştirme kaygısıyla hazırlanmış örnekler ders kitabında minimum seviyede tutulmalıdır. Öğretim programında matematiksel yetkinlik olarak tanımlanan becerileri metin yoluyla öğretme stratejisi benimsenmelidir. Örneğin, metnin olay örgüsünü değiştiren olayların gerilim grafiği çıkartılabilir, karakterlerin olaydaki etkisi sayısal olarak değerlendirilebilir, metinde kullanılan mekanların büyüklüğü küçüklüğü grafiklerle açıklanır ve bu grafik üzerinden metne yönelik bir zihni tablo oluşturulabilir. Ders kitaplarındaki metinler öğretim programının kazandırmak istediği becerilere ait kavramları kendi içinde açık bir şekilde ihtiva etmeli, bu şekilde öğrencide açık bir kavram farkındalığı sağlanmalıdır.

3. Üstbilişsel işlevlerin birey merkezli olduğu bilinse de burada en büyük misyon öğretmene düşmektedir. Yaş ve deneyimle doğal olarak gelişen bu beceri öğretmen katkısıyla daha erken dönemde bilinçli bir biçimde gelişebilir. Bunun için öğretmenler bu konuda hem lisans eğitimleri sırasında eğitilmeli hem de çalıșmaları esnasında bu bilgileri hayata geçirmelidir. Bunun için öğretmenler özellikle öğretim yılı planlanırken üstbiliş eğitimi için bazı amaçlar düzenlemeli bu amaçları ders işleme sürecinde metinler açımlanırken kullanmalıdır. Öğretmenler sınıfta bir modelleme oluşturmalı açık bir öğretim yolunu benimsemelidir. Özellikle sorular oluşturma konusunda s1k s1k metin işleme sürecinde pratik yapmalı ve öğrencinin üstbilişsel becerilerini tetikleyecek minvalde sorular oluşturmalıdır. Sınıfla birlikte kısa, orta ve uzun vadede amaçlar belirleyerek öğrencilere zaman planlamasını ve yönetimini deneyimletecek ortamlar sunmalıdır. Yüksek sesle düşünme ve kendini eleştirme konusunda sınıfı bir ayna gibi düşünmeli ve her gün o aynaya bir kere dahi olsa bakmalı ve bunları deneyimlemeli. Metinleri bilişsel ve üstbilişsel işlevler açısından değerlendirmesi soru sorma stratejisini bunun üzerine inşa etmeli.

\section{Kaynaklar}

Akın, A. ve Abacı, R. (2011). Biliş ötesi. Ankara: Nobel Yayıncılık. 
Baş, F. ve Özturan- Sağırlı, M. (2017). Türkiye'de eğitim alanında üstbiliş odaklı yapılan makalelere yönelik bir içerik analizi. Ĕgitim ve Bilim, 42(192), 1-33.

Bloom, B. S., Englehart, M. D., Furst, E. J., Hill, W. H. ve Krathwohl, D. R.(1956). Taxonomy of educational objectives: The classification of educational goals: Handbook $I$. Cognitive Domain. New York, NY: McKAY.

Brown, A. L. (1987). Metacognition, executive control, self-regulation and other even more mysterious mechanisms. F. Weinert ve R. Kluwe (Yay. haz). Metacognition, motivation and understanding içinde (ss. 65-116). Mahwah, NJ: Erlbaum.

Brown, A. L. (1977). Knowing when, where and how to remember: a problem of metacognition. University of Illinois at Urbana-Champaign, National Inst. of Education (DHEW): Washington, D. C.

Çakıroğlu, A. (2007). Üstbilişsel strateji kullanımının okuduğunu anlama düzeyi düşük ögrencilerde erişimi artırımına etkisi (Yayımlanmamış doktora tezi). Gazi Üniversitesi, Ankara.

Çalışkan, G. (2016). Türkçe dersi öğretim programı ve Türkçe ders kitapları: 5. sınıf Türkçe ders kitabına yönelik bir inceleme. Ana Dili Eğitimi Dergisi, 4(2), 200-214.

Çiçekçioğlu, D. (2003). Bilişsel ve üstbilişsel okuma stratejilerinin direk ve tümleşik olarak bilinçlendirme seviyesinde öğretiminin okuma yeterliliğine ve strateji kullanımına etkileri (Yayımlanmamış yüksek lisans tezi). Orta Doğu Teknik Üniversitesi, Ankara.

Demirel, M. ve Turan, B. A. (2010). Probleme dayalı öğrenmenin başarıya, tutuma, bilişötesi farkındalık ve güdü düzeyine etkisi. Hacettepe Üniversitesi Eğitim Fakültesi Dergisi, $38(38), 55-66$.

Demirel, Ö. (2001). Eğitim sözlüğ̈̈. Ankara: Pegem Yayınc1lık.

Demirsöz, E. S. (2010). Yaratıcı dramanın ögretmen adaylarının demokratik tutumları, bilişüstü farkindalıkları ve duygusal zeka yeterliliklerine etkisi (Yayımlanmamış doktora tezi). Dokuz Eylül Üniversitesi, İzmir.

Duru, M. K. (2007). Illkögretim fen bilgisi dersinde beyin firtınast ile ögretimin başarıya, kavram ögrenmeye ve bilişüstü becerilere etkisi (Yayımlanmamış doktora tezi). Marmara Üniversitesi, İstanbul.

Ekmen, H. (2009). 2005 programına göre hazırlanan 7. sınıf türkçe ders kitabının söz varlı̆̆ bakımından incelenmesi (Yayımlanmamış yüksek lisans tezi), Afyon Kocatepe Üniversitesi, Afyon.

Erden, M. ve Akman, Y. (1997). Eğitim psikolojisi- gelişim, öğrenme, öğretme. Ankara: Arkadaş Yayınevi.

Erdoğan, B. (2007). Bilişüstü yeti soruları içeren veya içermeyen somut materyal kullanımının 6. sınıf ögrencilerinin çokgen bilgilerine etkisi (Yayımlanmamış yüksek lisans tezi). Orta Doğu Teknik Üniversitesi, Ankara.

Flavell, J. H. (1976). Metacognitive aspects of problem solving. L. R. Resnick (Yay. haz.). The Nature of Intelligence. Hillsdale, NJ: Lawrence Erbaum.

Flavell, J. H. (1979). Metacognition and cognitive monitoring. American Psychologist. 34(10) 906-911.

Kan, M.O. (2010). Millî ĕgitim bakanlı̆̆ yayınları ilköğretim 7. sınıf türkçe ders kitabının kültür ögeleri açısından incelenmesi (Yayımlanmamış yüksek lisans tezi). Mustafa Kemal Üniversitesi, Hatay.

Köçer, N. (2010). Metin çözümlemesi Milli Eğitim Bakanlı̆̆ `nca önerilen 6. sinıf türkçe ders kitabındaki metinlerin metinsellik ölçütleri bağlamında çözümlenmesi (Yayımlanmamış yüksek lisans tezi). Marmara Üniversitesi, İstanbul.

Krathwohl, D. R. (2002). A revision of Bloom's taxonomy: an overview. Theory Into Practise, $41(4), 212-218$.

MEB. (2018). Ortaokul ve imam hatip ortaokulu 5. sınıf Türkçe ders kitabı. Ankara: Özgün Matbaacilik.

MEB. (2018). Ortaokul ve imam hatip ortaokulu 6. sınıf Türkçe ders kitabl. İstanbul: Netbil Basım ve Yayınc1lı. 
MEB. (2018). Ortaokul ve imam hatip ortaokulu 7. sınıf Türkçe ders kitabı. Ankara: Özgün Matbaacilik.

MEB. (2018). Ortaokul ve imam hatip ortaokulu 8. sınıf Türkçe ders kitabı. Ankara: Saray Matbaacilik.

MEB. (2018). Türkçe dersi ögretim programı (İlkokul ve Ortaokul 1, 2, 3, 4, 5, 6, 7 ve 8.Sinıflar). Ankara. Milli Eğitim Bakanlığı Temel Eğitim Genel Müdürlüğü.

Okur, S. (2008). PISA 2003 matematik okur yazarlı̆̆ soruları bağlamında ögrenci stratejileri, adımları ve üstbilişler (Yayımlanmamış doktora tezi). Orta Doğu Teknik Üniversitesi, Ankara.

Olgun, A. (2006). Bilgisayar destekli fen bilgisi ögretiminin ögrrencilerin fen bilgisi tutumları, bilişüstü becerileri ve başarılarına etkisi (Yayımlanmamış doktora tezi). Eskişehir Osman Gazi Üniversitesi, Eskişehir.

Osman, M. E. ve Hannafin, M. J. (1992). Metacognitive research and theory: analysis and implications for instructional design. Educational Technology Research and Development, 40(2), 83-99.

Özcan, Z. Ç. ( 2007). Sinıf ögrretmenlerinin derslerinde bilişüstü beceri gelişstiren stratejileri kullanma özelliklerinin incelenmesi (Yayımlanmamış doktora tezi). Marmara Üniversitesi, İstanbul.

Özkan, E. ve Bümen, N. (2014). Fen ve teknoloji dersinde araştırmaya dayalı öğrenmenin öğrencilerin erişilerine, kavram öğrenmelerine, üstbiliş farkındalıklarına ve fen ve teknoloji dersine yönelik tutumlarına etkisi. Ege Ĕ̈itim Dergisi. 15(1), 251-278.

Özsoy, G. (2006). Problem çözme ve üstbiliş. Ulusal Sınıf Öğretmenliği Kongresi Bildirileri (Cilt2). Ankara: Kök Yayıncılık.

Piaget, J. (1939). Çocukta hüküm ve muhakeme. İstanbul: Milli Eğitim Basımevi.

Schraw, G. ve Dennison, R. S. (1994). The effect of reader purpose on interest and recall. Journal of Reading Behavior: A Journal of Literacy, 26, 1-18.

Senemoğlu, N. (2018). Geliş̧im öğrenme ve ögretim kuramdan uygulamaya. Ankara: An1 Yayincilik.

Smith, E. E. ve Kosslyn S. M. (2014). Bilişsel psikoloji zihin ve beyin. M. Şahin (Çev. Edt.). Ankara: Nobel Yayıncilik.

Solak, M. ve Yaylı, D. (2009). İlköğretim ikinci kademe türkçe ders kitaplarının türler açısından incelenmesi. Uluslararası Sosyal Araştırmalar Dergisi.2(9), 444-453.

Şahin, S. (2015). Fen bilgisi ögretmen adaylarının bilişüstü farkındalık düzeyleri ile problem çözme becerilerinin incelenmesi (Yayımlanmamış yüksek lisans tezi). Gazi Üniversitesi Eğitim Bilimleri Enstitüsü, Ankara.

Topçu, A. ( 2005). Eş zamanlı olmayan web tabanlı dersin ögretmen adaylarının başarısına, zihin üstü yetilerine ve bilgisayara $w w w$ ve web tabanl derse karşı tutumlarına etkisi (Yayımlanmamış doktora tezi). Orta Doğu Teknik Üniversitesi, Ankara.

Vygotsky, L. (1978). Mind in society. USA: Harvard University Press.

Wellman, H. M. (1985). The origins of metacognition. D. L. Forrest-Presley, G.E. MacKinnon, T. ve GeryWaller (Yay. haz.). Metacognition, Cognition, and Human Performance. Orlando: Academic Press.

Yabaş, D. (2008). Farklılaştırılmış öğretim tasarımının öğrencilerin özyerlik algıları, bilişüstü becerileri ve akademik başarılarına etkisinin incelenmesi (Yayımlanmamış doktora tezi). Yıldiz Teknik Üniversitesi, İstanbul.

Yıldırım, A. ve Şimşek, H. (2018). Sosyal bilimlerde nitel araştırma yöntemleri. Ankara: Seçkin Yayincilik.

Yurt, G. ve Arslan, M. (2014). 7. sınıf türkçe ders kitaplarının şekil-içerik-metin yönünden incelenmesi. SDÜ Fen Edebiyat Fakültesi Sosyal Bilimler Dergisi, 31, 317-327.

Zimmerman, B. (2000). Attaining self-regulation: a social cognitive perspective. M. Boekaerts, P.R. Pintrich, ve M. Zeidner (Yay. haz.), Handbook of self- regulation içinde (ss. 1339). San Diego, CA: Academic Press. 


\section{Extended Abstract}

\section{Introduction}

Human beings define their consciousness and identity in time and space. Cognition emerges as a product of the echo of the individual between space and time on the axis of consciousness. Bringing cognition to the forefront in the education process has been formed on the purpose of sensing the difference between yesterday and today's impression to the individual. All of our mental activities are related to "something Smith (Smith \& Kosslyn, 2014, p. 11). The concept of "thing ep is an epistemological and ontological problematic. While the mind puts forward actions on this problem, it builds possibilities through representations on itself, destroys them and even reestablishes them. The mind performs this construction and destruction on the quest for "meaning. The brain is a processing system where notions of meaning and cognition are collected. This processing, ie brain activity, occurs mainly by the activity of neurons.

\section{Method}

In this research, case study, which is one of the qualitative research designs, was used. Intertwined multiple state patterns from four types of state patterns constituted the method of the study due to the cognitive and metacognitive functions determined by taking expert opinion. In a nested multi-case pattern, each case discussed or included in the study can be studied by subdividing itself into various sub-units (Yıldırım \& Şimşek, 2018, p. 302). In this respect, cognitive and metacognitive functions were divided into sub-categories within the study itself, and the questions prepared for teachers' opinions were shaped by the principle of lower and upper categories due to this study design.

Criterion sampling, one of the purposeful sampling methods, was used in the study. The basic understanding of the criterion sampling method is defined as the study of all situations that meet a set of criteria (Yıldırım \& Şimşek, 2018, p. 122).

The study group of the study consisted of secondary school Turkish teachers working in the central districts of Ankara. The number of teachers contributing to the research was 12. 10 of the teachers are women and 2 are men. Considering the professional experience of the teachers, it was determined that most of them had 8-10 years of working experience. 11 of the teachers are undergraduate graduates and 1 of them is $\mathrm{PhD}$.

In this study, three data collection tools were used: Standardized open-ended interview questions, cognitive and metacognitive functions criterion and document analysis prepared by expert opinion.

\section{Result and Discussion}

Results of the summarization function. In the textbooks, the skill of having a heavy cognitive load was requested from the student in order to operate all the processes each time by perceiving the summation gain as an activity. Although summation is a skill that requires a process, the textbooks have adopted a method of assessment and evaluation, which is result-oriented and without acquiring the processes to the student. The concept of summarization identified in the 7 th grade (2) textbook is used only in a single text and to reflect the meaning of "in short, as a result".

The results of the conversion-translation function. It is defined as a mathematical competence in the curriculum (MEB Curriculum, 2018, p. 5) and basic competence in science / technology. With the inclusion of this in the curriculum, the content of the textbooks was created with graphics, tables, mind and concept maps at this point. However, this skill has been included in textbooks as result-oriented and text-independent application examples rather than a skill that needs to be developed in the process with texts. This skill in the textbook is frequently seen in the point of dönüştürme converting the text type "and" transforming the in-text character". Converting an image to text, converting the listening to an image, transforming the narrator, transforming the character (from singular to singular III, etc.), and transforming the character (empathetic transforming) were the preferred types of conversion. However, the text 
was designed as a data source and there was no way to prepare any tables or graphics based on that data.

The curriculum has designed the concept of metacognition as a final outcome and has made it its goal. But the interesting thing is that the curriculum is sometimes perceived as skill (MEB Curriculum, 2018, p. 3) and sometimes as personal development (MEB Curriculum, 2018: 17). Where it is perceived as a skill, it examined this concept under the title of kinlik Competencies ve and in the next stage conceptualized it as ögrenme learning to learn.. After doing this, while he listed the themes to be included in the textbooks, he considered the skills as the theme of Gelişim Personal Development "and referred them as topics within the theme. The concepts called subject are self-regulation, self-regulation, self-knowledge, self-esteem, selfesteem, self-efficacy, time management" (MEB Curriculum, 2018, p. 17). Experienced these semantic contradictions are a conflict of specified purposes and methods, Turkey Qualifications Framework generic competencies and then detected in the "subject" by the return of concepts ... It seems that the internal consistency provided not a result of the program laid out in textbooks within the text and text six questions it cannot be a hierarchical, coherent and complex mechanism that serves the aforementioned concepts. 